\title{
A herpes-like virus infects a non-ostreid bivalve species: virus replication in Ruditapes philippinarum larvae
}

\author{
Tristan Renault*, Cécile Lipart, Isabelle Arzul \\ Institut Français de Recherche pour l'Exploitation de la Mer, Laboratoire de Génétique et Pathologie, BP 133, \\ 17390 La Tremblade, France
}

\begin{abstract}
Sporadic high mortalities were reported in June 1997 among hatchery-reared larval Manila clam Ruditapes philippinarum in a French commercial hatchery. Cellular abnormalities were observed in semi-thin sections in affected animals. Transmission electron microscopy revealed the presence of herpes-like virus particles in larvae. This is the first description of a herpes-like virus infection in larval $R$. philippinarum, a non-ostreid bivalve species. Virus particles were similar to other herpes-like viruses described from different oyster species with respect to ultrastructure and morphogenesis. Electron microscopic examination also demonstrated cells with condensed chromatin and extensive perinuclear fragmentation of chromatin. Like viruses infecting oysters, the herpes-like virus detected in clams may induce apoptosis in infected animals.
\end{abstract}

KEY WORDS: Herpes-like virus $\cdot$ Manila clam $\cdot$ Ruditapes philippinarum $\cdot$ Mortality $\cdot$ Virus replication · Apoptosis

Resale or republication not permitted without written consent of the publisher

\section{INTRODUCTION}

Several herpes-like virus infections have been reported from different oyster species around the world. The first observation was by Farley et al. (1972) in Crassostrea virginica adults. More recently, a herpeslike virus was demonstrated in larvae of hatcheryreared Pacific oyster Crassostrea gigas in France during summer 1991 (Nicolas et al. 1992). Further outbreaks of herpes-like virus infections were noted during the summer period each year in some French hatcheries in Pacific oyster larvae (Renault et al. 1994a). Since 1993, sporadic high mortalities have occurred in some batches of Pacific oyster spat cultured in different French locations (Renault et al. 1994b). A herpes-like virus was also reported in association with mortalities in French Ostrea edulis spat in Brittany (Comps \& Cochennec 1993). Hine et al. (1992) described a herpes-like virus infection responsible for mortality of hatchery-reared C. gigas larvae

*E-mail: trenault@ifremer.fr in New Zealand. Herpes-like viruses were also observed in haemocytes of Ostrea angasi adults in Australia (Hine \& Thorne 1997) and in larval New Zealand flat oysters Tiostrea chilensis (Hine et al. 1998). All these viruses are similar with respect to morphology and cellular localisations and so far have only been detected in Ostreidae (Renault 1998). We describe herein for the first time a herpes-like virus infecting Manila clam larvae, a non-ostreid bivalve species. An ultrastructural comparative study between herpes-like viruses found in France among Pacific oysters, European flat oysters and Manila clams was performed.

\section{MATERIAL AND METHODS}

Specimens. Moribund Ruditapes philippinarum larvae, 13 d old, were collected in June 1997 from a private hatchery located in Normandy (France).

Light microscopy and transmission electron microscopy. Moribund larvae were directly fixed in glutaraldehyde for light and transmission electron micro- 
scopy. The larvae were fixed in $2.5 \%$ glutaraldehyde in $0.2 \mathrm{M}$ cacodylate buffer at $\mathrm{pH} 7.2$ for $1 \mathrm{~h}$ at $4^{\circ} \mathrm{C}$. After 2 washes in cacodylate buffer, samples were post-fixed in $1 \%$ osmium tetroxide in the same buffer at $4^{\circ} \mathrm{C}$. Larval samples were dehydrated by serial ethanol baths (70 to $100 \%$ ), partially rehyrated by two $10 \mathrm{~min}$ baths in $0.2 \mathrm{M}$ cacodylate buffer and de-calcified with a $2 \%$ ethylenetetra-acetic acid (EDTA) solution in $0.2 \mathrm{M}$ cacodylate buffer overnight at $4^{\circ} \mathrm{C}$. After fixation and post-fixation, larvae were washed in $0.2 \mathrm{M}$ cacodylate buffer, dehydrated by means of an ascending ethanol series (70 to $100 \%$ ), cleared twice for $15 \mathrm{~min}$ in propylene oxide and infiltrated for $1 \mathrm{~h}$ in 50:50 propylene oxide:Epon resin. After $1 \mathrm{~h}$ infiltration in pure Epon resin, they were embedded in resin and cured for $48 \mathrm{~h}$ at $60^{\circ} \mathrm{C}$. Sections were cut at $1 \mu \mathrm{m}$ for light microscopic examination which were stained in $0.5 \%$ toluidine blue in $1 \%$ sodium borate solution. Ultrathin sections were stained in $5 \%$ uranyl acetate in $50 \%$ ethanol for $20 \mathrm{~min}$ and in $5 \%$ lead citrate in fresh boiled distilled water for $3 \mathrm{~min}$. They were examined in a JEOL JEM 1200 EX transmission electron microscope at $80 \mathrm{kV}$.

\section{RESULTS}

\section{Course of the disease}

A few days after spawning, Ruditapes philippinarum larvae showed reduction in feeding and swimming activities. Mortality occurred, at the beginning of June 1997, with total mortality by Day 13. Affected larvae swam weakly in circles before dying appromimately at 100 to $150 \mu \mathrm{m}$ in size.

\section{Histological examination}

Abnormal nuclei were present throughout the connective tissue in semi-thin sections of moribund larvae. Enlarged nuclei with abnormal marginated chromatin were evident in fibroblastic-like cells (Fig. 1). Highly condensed nuclei were observed in ovoid cells interpreted as haemocytes. Some nuclei of fibroblastic-like cells and haemocytes appeared with a ring-shaped or crescent-shaped chromatin (Fig. 1). The lesions were mainly confined to connective tissues, but a few epithelial cells also showed abnormal nuclei with condensed chromatin.

\section{Electron microscopical examination}

Infected fibroblastic-like cells showed hypertrophied nuclei and marginated chromatin (Fig. 2). Some nuclei

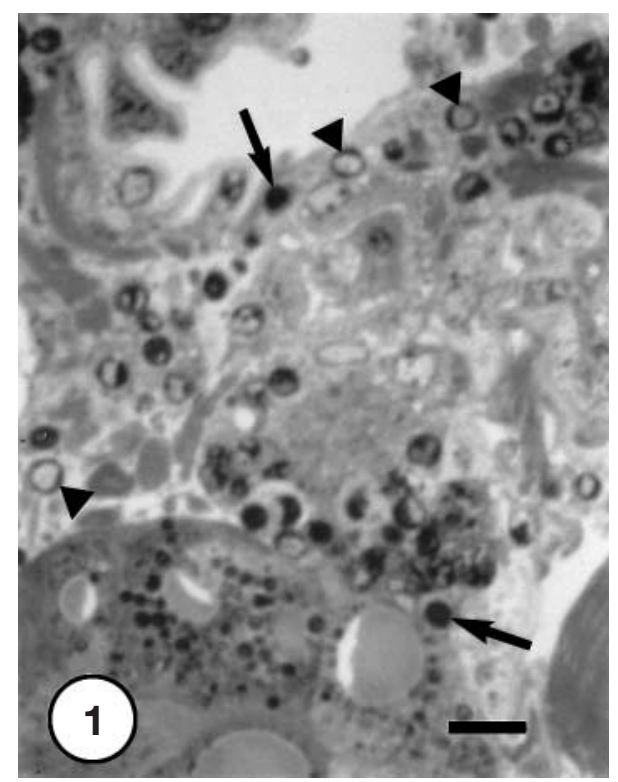

Fig. 1. Toluidine blue semi-thin section of Ruditapes philippinarum larva showing abnormal cells with condensed nuclei (arrows) and chromatin margination (arrowheads). Scale bar $=5 \mu \mathrm{m}$

were seen to collapse and were highly electron dense, showing a crescent-shaped condensation of the chromatin (Figs. $3 \& 4$ ). Chromatin was densely packed around the nuclear envelope and eventually rounded

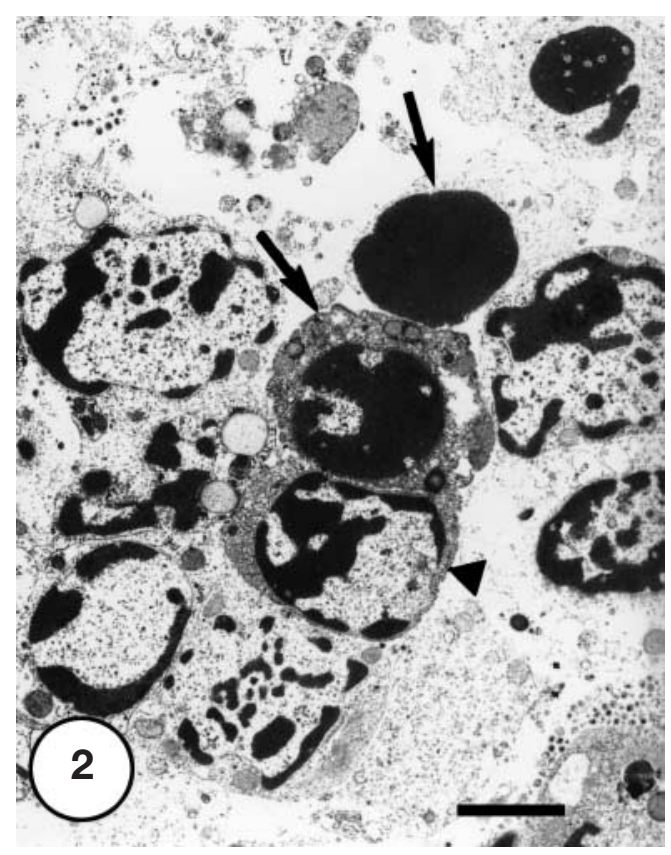

Fig. 2. Transmission electron micrographs of larval connective tissue showing hypertrophied nuclei with marginated chromatin (arrowhead) and condensed nuclei (arrows). Scale bar $=2 \mu \mathrm{m}$ 


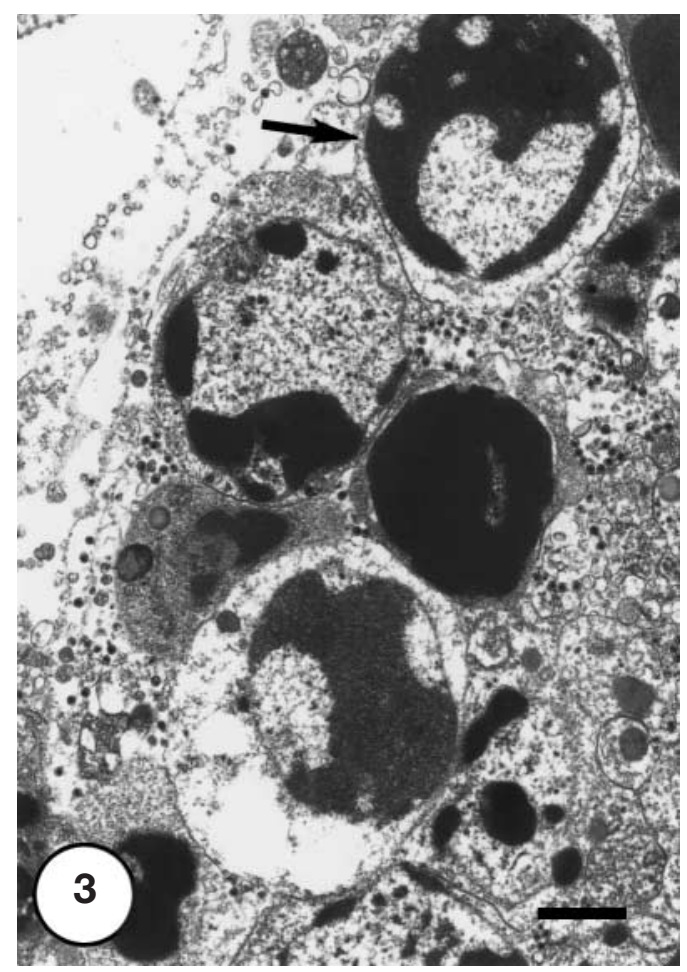

Fig. 3. Transmission electron micrographs of larval connective tissue showing condensed nuclei with ring-shaped chromatin patterns (arrow): Scale bar $=1 \mu \mathrm{m}$

up into a single sphere (Figs. $3 \& 4$ ). Cell shrinkage was associated with chromatin condensation (Fig. 4). The cell shrunk, losing as much as $30 \%$ of its volume, while the cytoplasmic contents were compacted (Figs. $3 \& 4$ ).
Table 1. Morphological characteristics of herpes-like virus particles observed in Ruditapes philippinarum, Crassostrea gigas and Ostrea edulis larvae in France. n: sample size

\begin{tabular}{|lccc|}
\hline Host species & Capsids & $\begin{array}{l}\text { Nucleo- } \\
\text { capsids } \\
(\mathrm{n}=25)\end{array}$ & $\begin{array}{c}\text { Enveloped } \\
\text { virions } \\
(\mathrm{n}=25)\end{array}$ \\
\hline R. philppinarum & $82 \pm 4 \mathrm{~nm}$ & $74 \pm 4 \mathrm{~nm}$ & $111 \pm 5 \mathrm{~nm}$ \\
C. gigas & $81 \pm 5 \mathrm{~nm}$ & $75 \pm 4 \mathrm{~nm}$ & $117 \pm 5 \mathrm{~nm}$ \\
O. edulis & $85 \pm 5 \mathrm{~nm}$ & $76 \pm 4 \mathrm{~nm}$ & $118 \pm 8 \mathrm{~nm}$ \\
\hline
\end{tabular}

The plasma membrane was folded but remained intact, and cell contents were not shed extracellularly (Fig. 4b). Condensation of the chromation and cell shrinkage were mostly observed in ovoid cells, 6 to $8 \mu \mathrm{m}$ in size, in connective tissues (Figs. 3 \& 4). These cells were assumed to be haemocytes on the basis of morphological features. The same ultrastructural changes were most rarely observed in fibroblastic-like cells and viral particles were rarely detected in cells containing highly condensed chromatin (Fig. 4). Degenerating and lysing infected nuclei and cells were observed frequently (Fig. 5). Abnormal accumulations of granular endoplasmic reticulum were often associated with infection (Fig. 6).

Intranuclear virus-like particles (Fig. 7) were mainly observed in fibroblastic-like cells and rarely in haemocytes. The nuclear particles were circular or polygonal in shape, 74 to $86 \mathrm{~nm}$ in diameter (Table 1). Some nuclear particles appeared empty and were interpreted as being capsids (Fig. 7); others contained an
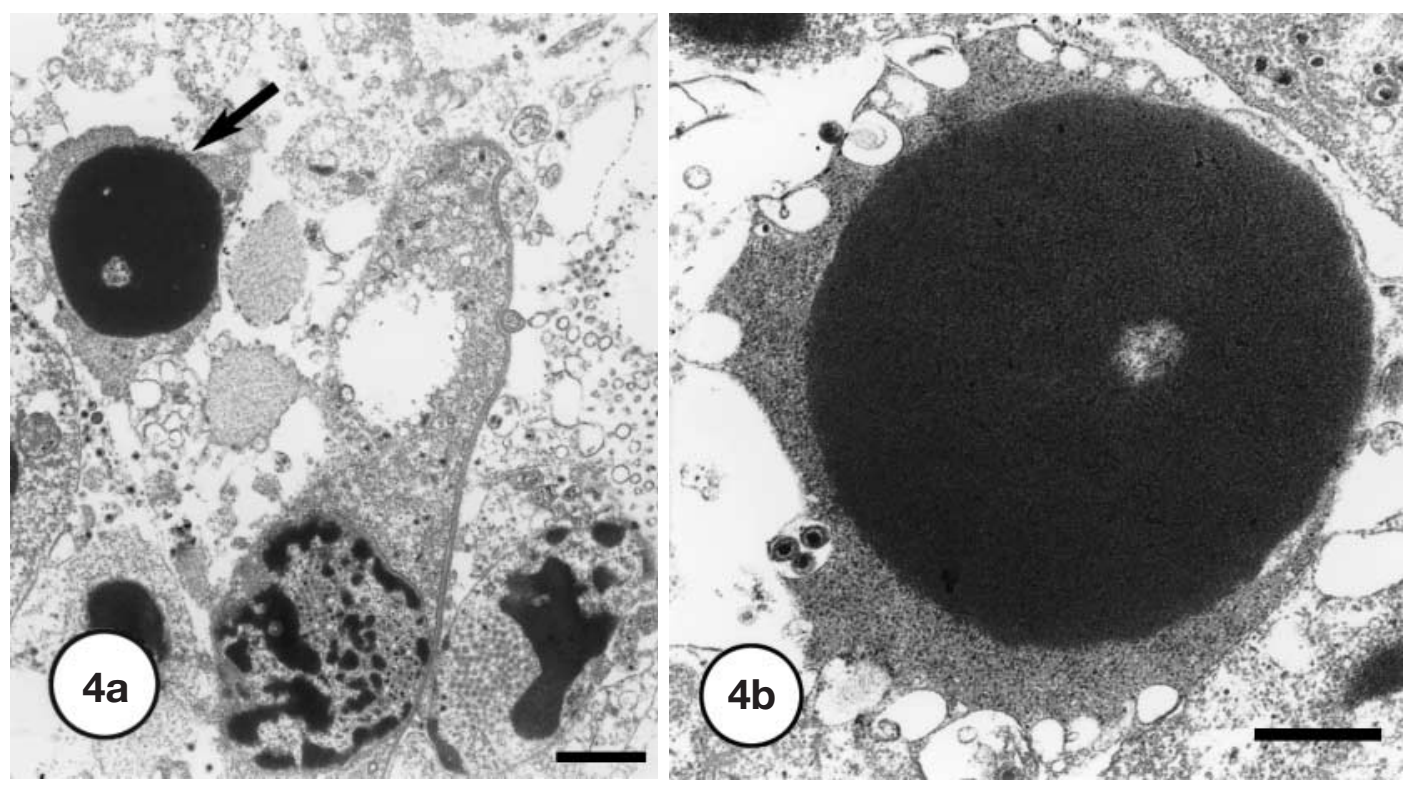

Fig. 4. Abnormal cells with condensed nuclei in larval connective tissue. (a) Abnormal cell with a condensed nucleus (arrow). Scale bar $=500 \mathrm{~nm}$. (b) High magnification of an abnormal cell with condensed nucleus and cytoplasm. Scale bar $=500 \mathrm{~nm}$ 


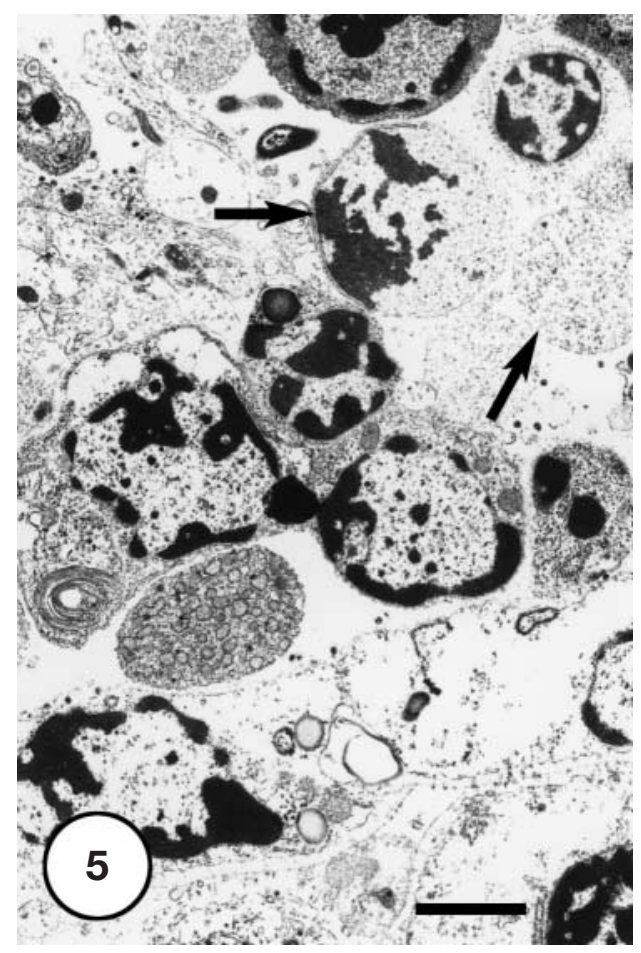

Fig. 5. Degenerating and lysing infected cells and nuclei (arrows). Scale bar $=2 \mu \mathrm{m}$

electron-dense toroidal, a brick-shaped core or a concentric ring structure. They were assumed to be nucleocapsids (Fig. 7). Capsids and nucleocapsids were

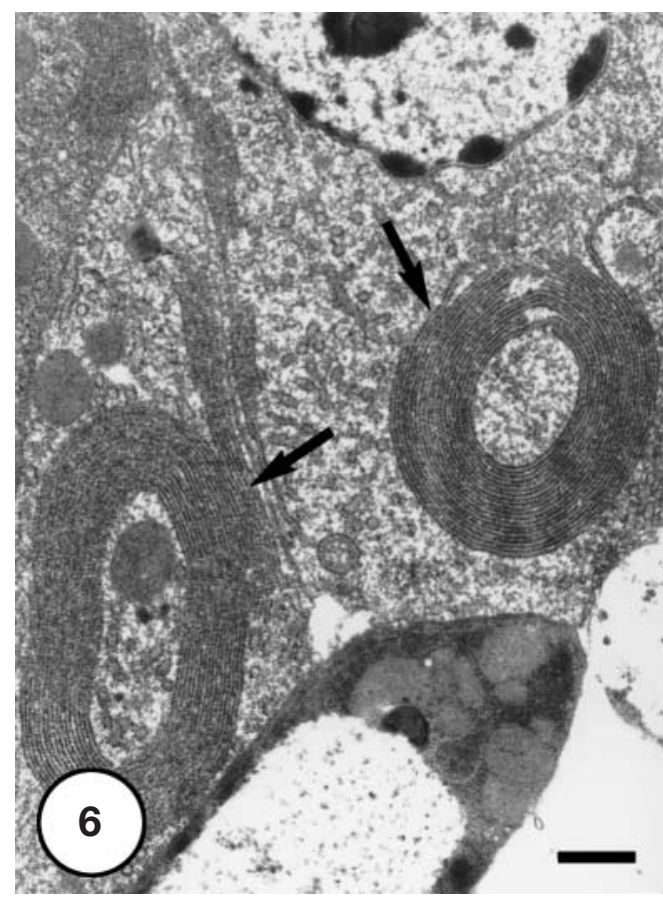

Fig. 6. Abnormal accumulation and reduplication of granular endoplasmic reticulum (arrows). Scale bar $=500 \mathrm{~nm}$

scattered throughout the nucleus of infected cells (Fig. 7). Some empty capsids appeared in the nucleus of infected cells with a paracrystalline structure (Fig. 8). Cytoplasmic nucleocapsids were seen near
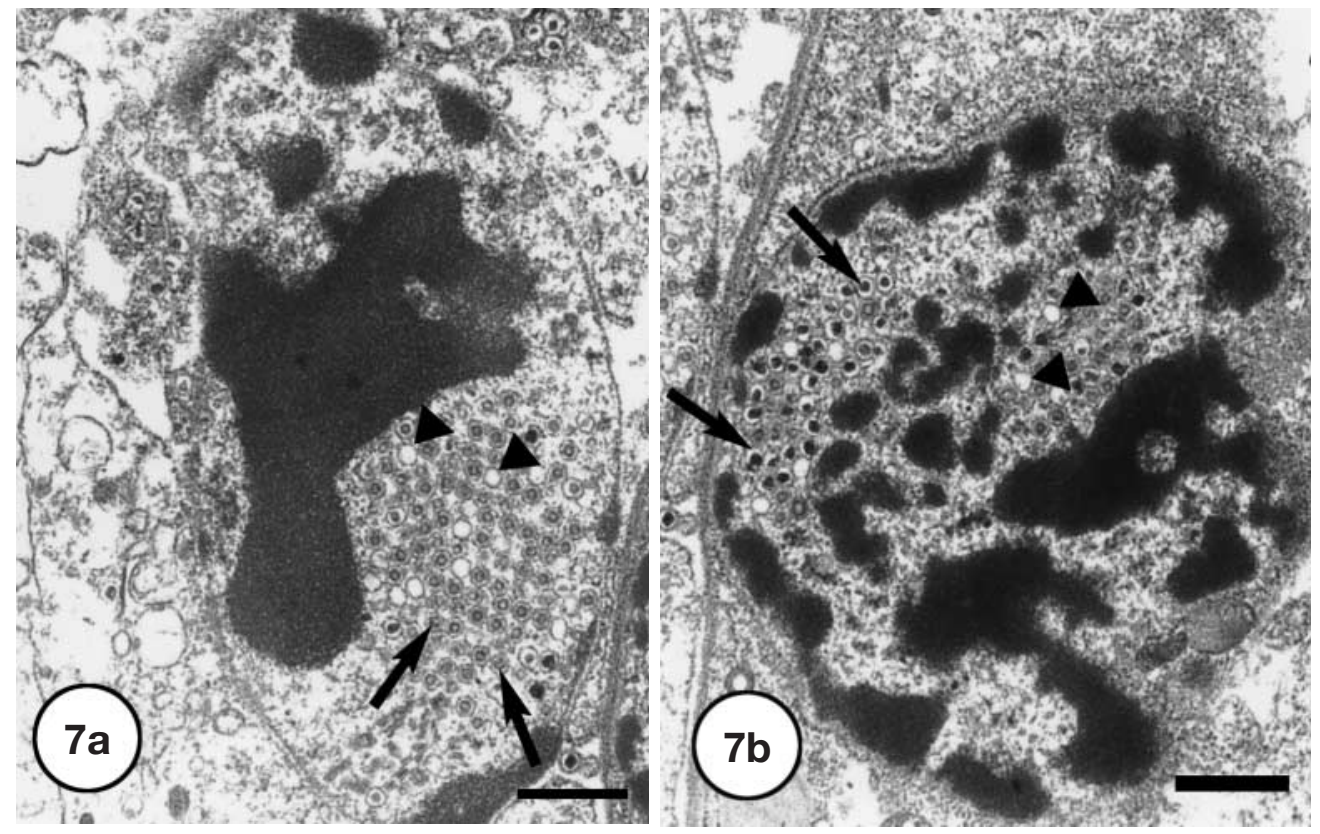

Fig. 7. Nuclei of infected interstitial cells containing empty capsids and nucleocapsids. (a) Empty capsids (arrowheads) and nucleocapsids with a double concerntric structure (arrows). Scale bar $=500 \mathrm{~nm}$. (b) Empty capsids (arrowheads) and nucleocapsids with a toroidal core (arrows). Scale bar $=500 \mathrm{~nm}$ 


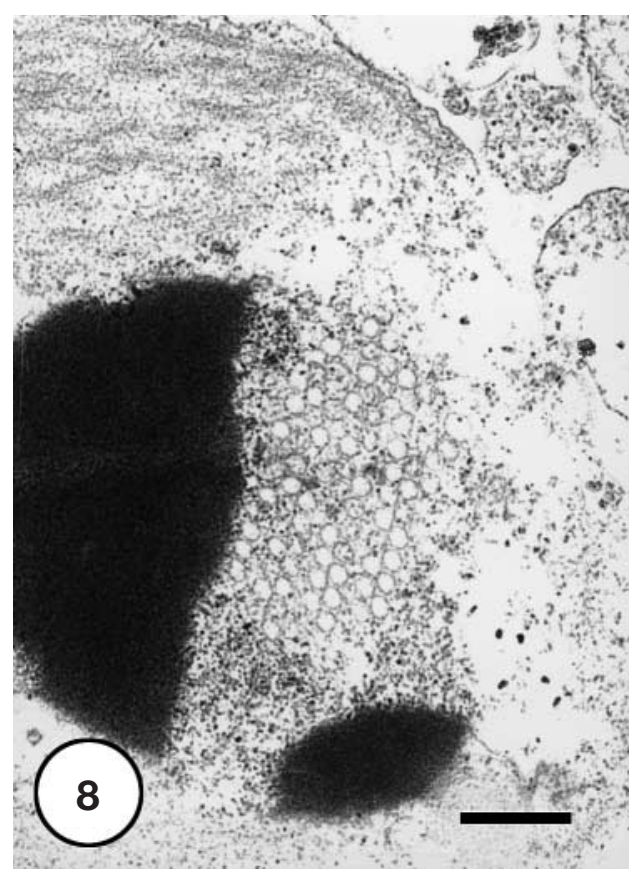

Fig. 8. Empty capsids in the nucleus of an infected cell presenting a paracrystalline arrangement. Scale bar $=500 \mathrm{~nm}$

vesicles into which they passed and became enveloped (Fig. 9). These intracytoplasmic particles exhibited an envelope formed by a trilaminar unit-membrane. They contained identically shaped and sized elements, with the same structures as the nuclear particles. Envelope and capsid were separated by an electron-lucent gap of approximately $5 \mathrm{~nm}$. Evidence of nucleocapsid envelopment involving passage of the nucleocapsid through the inner nuclear lamina into the perinuclear space was rarely observed (data not shown). Extracellular viruses were usually enveloped and measured around $110 \mathrm{~nm}$ in diameter (Table 1, Fig. 10). A tail was rarely observed (Fig. 10 b). No obvious tegument or reduced tegument was observed between the outer membrane and the capsid (Fig. 10).

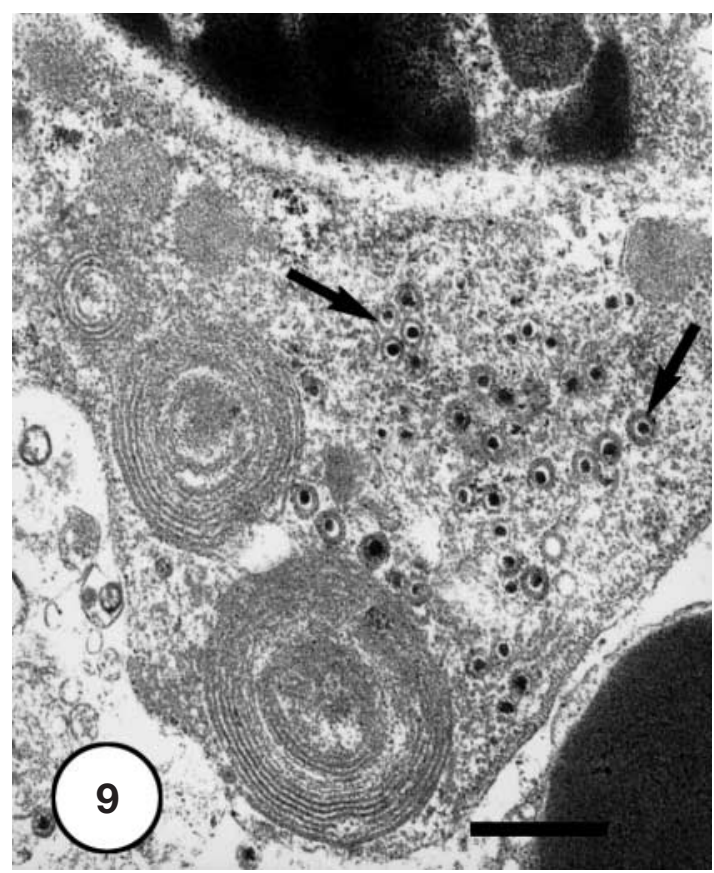

Fig. 9. Capsids or groups of capsids within membranes (arrows) in the cytoplasm. Scale bar $=500 \mathrm{~nm}$

\section{DISCUSSION}

Several herpes-like virus infections have been reported in marine vertebrates and invertebrates, including ostreid bivalves (Farley et al. 1972, Hine et al. 1992, Nicolas et al. 1992, Comps \& Cochennec 1993, Renault et al. 1994a, Hine \& Thorne 1997, Hine et al. 1998). We describe for the first time a herpes-like virus in Manila clam larvae associated with high mortality rates in France. Virogenesis occurs mainly in cells interpreted as fibrobalstic-like cells on the basis of morphological features and locations in infected Ruditapes philippinarum larvae. Viral particles are rarely observed in haemocytes. The virus reported in $R$. philippinarum larvae resembles herpesviruses of both

Fig. 10. Extracellular enveloped virus particles. (a) Extracellular enveloped virus particles underlying the cell membrane. Scale bar $=500 \mathrm{~nm}$. (b) High magnification of extracellular enveloped particles showing a tail (arrow). Scale bar = $100 \mathrm{~nm}$
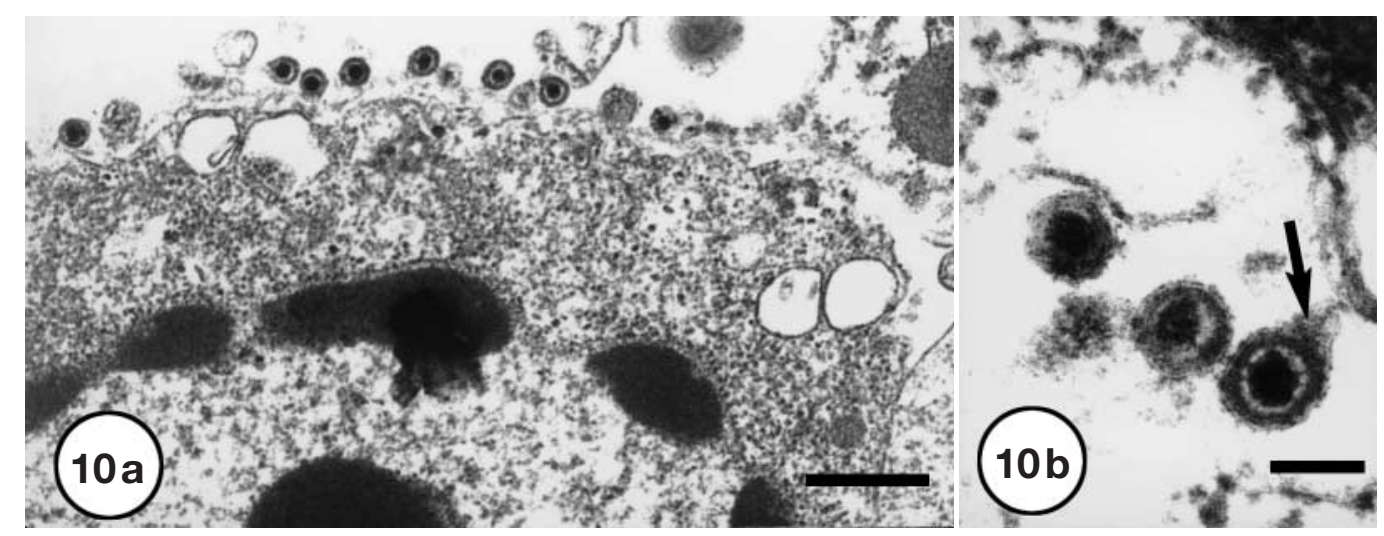
higher vertebrates and lower vertebrates in size and capsid genesis (Roizman 1982a, Roizman \& Baines 1991). In thin sections of tissues of infected larvae, nucleocapsids occur in a variety of morphological forms. Some capsids lack an electron-dense core and can be referred to as empty (Perdue et al. 1976). Nucleocapsids include a variety of capsid types: toroidal core containing capsids referred to as 'DNA rich' (Perdue et al. 1975), capsids with an electron-lucent, cross-shaped internal structure and capsids that appear as 2 concentric rings.

The herpes-like virus reported in France in hatchery-reared Ruditapes philippinarum appears closely related to the viruses described in Crassostrea gigas and Ostrea edulis larvae. They have the same structural characteristics, the same cellular localisations and similar sizes (Table 1). The virogenesis for viruses detected in Manila clams, Pacific oysters and European flat oysters begins in the nucleus where capsids and nucleocapsids are detected. Condensation of nuclear chromatin and paracrystalline arrangement of empty capsids have been reported from both $O$. edulis and $C$. gigas. Infection of fibroblastic-like cells and a few haemocytes in $R$. philippinarum larvae is similar to herpes-like viral infections in $O$. edulis and $C$. gigas.

Increasing evidence indicates that apoptosis may occur in several different viral infections, including those caused by members of the Herpesviridae family (Chou \& Roizman 1992, Kruerger et al. 1995, Hanon et al. 1996, Koyoma \& Miwa 1997, Mastino et al. 1997, Wilson et al. 1997, Kieff \& Shenk 1998). Apoptosis may occur during herpes-like virus infections in bivalves (Renault 1998, Renault et al. 2000a). Condensation of the chromatin and cell shrinkage observed in infected Manila clam larvae are also morphological characteristics of cells undergoing apoptosis. A cell undergoing apoptosis rounds up and the collapse of the nucleus is the hallmark of apoptosis (Cohen 1998). The chromatin rapidly forms dense crescent-shaped aggregates lining the nuclear membrane (Cohen 1998). At the same time the cytoplasm condenses but the morphology of mitochondria and ribosomes is preserved (Cohen 1998). In apoptosis, the nuclear changes precede the loss of membrane integrity. The ultrastructural changes observed in Ruditapes philippinarum larvae appear characteristic of apoptosis. Chromatin aggregation resulting in the formation of an electron-dense nuclear matrix is reported in infected animals. Characteristic apoptotic nuclei with marginalized and condensed chromatin are also appreciable. These ultrastructural changes are mainly observed in haemocytes and most rarely in fibroblastic-like cells. Herpes-like virus in $R$. philippinarum larvae may be able to kill haemocytes, the cells involved in defence mechanisms. Several herpesviruses have been shown to infect and induce apoptosis in activated peripheral blood T lymphocytes (Kieff \& Shenk 1998). Activated T lymphocytes play an important role in the clearance of local herpesvirus infections and their destruction can delay viral clearance, facilitating the spread of viruses in hosts. The induction of apoptosis provides a means for the virus to establish a balanced long-term relationship with the host immune system, sacrificing some virus and some lymphocytes while permitting other cells to undergo infection and thereby promoting viral survival. Cell death is induced as a result of an abortive infection, perhaps as early as at the time of attachment or penetration. Thus, herpes simplex viruses 1 and 2 bind to a cell surface protein related to the tumor necrosis factor receptor termed HVEM (Montgomery et al. 1996). Since the tumor necrosis factor receptor transduces pro- or antiapoptotic signals, binding of the virus to HVEM can mediate apoptosis under certain conditions.

We report herein for the first time a herpes-like viral infection in a non-ostreid bivalve species. The detection of herpes-like viruses in several bivalves belonging to different genera highlights the risk of rearing different mollusc species together. Concomitant herpes-like viral infections have already been reported by transmission electron microscopy in hatchery- and nursery-reared Crassostrea gigas and Ostrea edulis oysters (Renault et al. 2000a). Interspecies transmission appears possible under hatchery rearing conditons. This hypothesis is reinforced by molecular analysis of herpesviruses infecting different bivalve species (I.A. unpubl. data). Herpes-like virus purification from infected C. gigas larvae and virus DNA extraction (Le Deuff \& Renault 1999) has permitted the development of specific molecular tools (Renault \& Lipart 1998, Renault et al. 2000b), and molecular analysis suggests that the same virus infects several bivalve species belonging to different genera. Thus, the detection of a herpes-like virus in a particular bivalve batch presenting anomalous mortalities may indicate that precautions should be taken in order to avoid the spread of the viral infection to all breedings.

Acknowledgements. This study could not been completed without the valuable help of some private French hatcheries. This research was supported in part by the Conseil Général de la Charente Maritime and the Région Poitou-Charentes.

\section{LITERATURE CITED}

Chou J, Roizman B (1992) The $\gamma 134.5$ gene of herpes simplex virus 1 precludes neuroblastoma cells from triggering total shuoff of protein synthesis characteristic of programmed cell death in neuronal cells. Proc Natl Acad Sci USA 89: 3266-3270

Cohen JJ (1998) Apoptosis: physiologic cell death. J Lab Clin Med 124(6):761-765 
Comps M, Cochennec N (1993) A herpes-like virus from the European oyster Ostrea edulis L. J Invertebr Pathol 62: 201-203

Farley CA, Banfield WG, Kasnic G Jr, Foster WS (1972) Oyster herpes-type virus. Science 178:759-760

Hanon E, Vanderplasschen A, Lyaku J, Keil G, Denis M, Pastoret PP (1996) Inactivated bovine herpesvirus 1 induces apoptotic cell death of mitogen-stimulated bovine peripheral blood mononuclear cells. J Virol 70(6):4116-4120

Hine PM, Thorne T (1997) Replication of herpes-like viruses in haemocytes of adult flat oysters Ostrea angasi (Sowerby, 1871): an ultrastructural study. Dis Aquat Org 29(3):197-204

Hine PM, Wesney B, Hay BE (1992) Herpesvirus associated with mortalities among hatchery-reared larval Pacific oysters Crassostrea gigas. Dis Aquat Org 12(2):135-142

Hine PM, Wesney B, Besant P (1998) Replication of herpeslike viruses in larvae of the flat oyster Tiostrea chilensis at ambient temperatures. Dis Aquat Org 32(3):161-171

Kieff E, Shenk T (1998) Modulation of apoptosis by herpesviruses. Semin Virol 8:471-480

Koyoma AH, Miwa Y (1997) Suppression of apoptotic DNA fragmentation in herpes simplex virus type 1-infected cells. J Virol 71(3):2567-2571

Krueger GR, Buja LM, Rojo J, Lasch J, Koch B, Leyssens N (1995) Apoptosis and cell proliferation in HHV-6 infections. Regulatory mechanisms of p53/bcl-2/ras interactions. Pathologe 16:120-127

Le Deuff RM, Renault T (1999) Purification and partial genome characterization of a herpes-like virus infecting the Japanese oyster, C. gigas. J Gen Virol 80:1317-1322

Mastino A, Sciotino MT, Medici MA, Perri D, Ammendolia MG, Grelli S, Amici C, Pernice A, Guglielmino S (1997) Herpes simplex virus 2 causes apoptotic infection in monocytoid cells. Cell Death Differ 4:629-638

Montgomery RI, Warner MS, Lum BJ, Spear PG (1996) Herpes simplex virus-1 entry into cells mediated by a novel member of the TNF/NGF receptor family. Cell 87:427-436

Nicolas JL, Comps M, Cochennec N (1992) Herpes-like virus

Editorial responsibility: Albert Sparks,

Seattle, Washington, USA infecting Pacific oyster larvae, Crassostrea gigas. Bull Eur Assoc Fish Pathol 12(1):11-13

Perdue ML, Cohen JC, Kemp MC, Randall CC, O'Callaghan DJ (1975) Characterization of three species of nucleocapsids of equine herpesvirus type 1 (EHV-1). Virology 64: 187-195

Perdue ML, Cohen JC, Randall CC, O'Callaghan DJ (1976) Biochemical studies of the maturation of herpesvirus nucleocapsid species. Virology 74:194-210

Renault T (1998) Infections herpétiques chez les invertébrés: détection de virus de type herpès chez les mollusques bivalves marins. Virologie 2:401-403

Renault T, Lipart C (1998) Diagnosis of herpes-like virus infections in oysters using molecular techniques. Eur Aquacult Soc (Spec Publ) 26:235-236

Renault T, Cochennec N, Le Deuff RM, Chollet B (1994a) Herpes-like virus infecting Japanese oyster (Crassostrea gigas) spat. Bull Eur Assoc Fish Pathol 14(2):64-66

Renault T, Le Deuff RM, Cochennec N, Maffart P (1994b) Herpesviruses associated with mortalities among Pacific oyster, Crassostrea gigas, in France-comparative study. Rev Méd Vét 145(10):735-742

Renault T, Le Deuff RM, Chollet B, Cochennec N, Gérard A (2000a) Concomitant herpes-like virus infections in hatchery-reared larvae and nursery-cultured spat Crassostrea gigas and Ostrea edulis. Dis Aquat Org 42(3):173-183

Renault T, Le Deuff RM, Lipart C, Delsert C (2000b) Development of a PCR procedure for the detection of a herpes-like virus infecting oysters in France. J Virol Methods 88:41-50

Roizman B (1982) The familly Herpesviridae. General description, taxonomy and classification. In: Roizman B (ed) The viruses, Vol 1. Herpesviruses. Plenum Press, New York, p 1-23

Roizman B, Baines J (1991) The diversity and unity of Herpesviridae. Comp Immun Microbiol Infect Dis 14(2):63-79

Wilson SE, Pedroza L, Beuerman R, Hill JM (1997) Herpes simplex virus type-1 infection of corneal epitheliall cells induces apoptosis of the underlying kertocytes. Exp Eye Res 64:775-779

Submitted: May 9, 2000; Accepted: January 12, 2001

Proofs received from author(s): April 18, 2001 